\author{
MUSTAFA SWITAT \\ (D) https://orcid.org/0000-0003-2727-1444 \\ Uniwersytet Warszawski \\ Warszawa
}

\title{
Polityka integracyjna Polski a integracja kulturowa społeczności arabskiej w Polsce
}

\author{
Poland's integration policy and \\ cultural integration of the Arabic community in Poland
}

\begin{abstract}
The aim of the paper is to present selected aspects of integration (in the cultural sense) of the Arabic community in Poland in the context of Poland's integration (migration) policy which Poland formally does not have at present. What Arabic and Polish respondents have to say about the integration process may be useful for the more efficient management of the immigration phenomenon.

Key words: integration policy, Poland, cultural integration, Arabic community, immigration phenomemon
\end{abstract}

Celem artykułu jest prezentacja wybranych aspektów integracji (kulturowej) społeczności arabskiej w Polsce w kontekście polityki integracyjnej (migracyjnej), której - formalnie - Polska nie posiada. Zagadnienia powiązane z procesami integracji zostana przedstawione z punktu widzenia przedstawicieli diaspory arabskiej w Polsce oraz badanych Polaków ${ }^{1}$. Należy przy tym

${ }^{1}$ Dane empiryczne wykorzystane w tym artykule to efekt badań terenowych przeprowadzonych od maja 2013 do marca 2014 roku z zastosowaniem triangulacji, czyli połączenia kilku metod i technik badawczych: wywiadów eksperckich, obserwacji uczestniczącej, a w przypadku badań zasadniczych: IDI (individual in-depth interview), czyli indywidualnych wywiadów pogłębionych w przypadku starej diaspory i wywiadów kwestionariuszowych w przypadku nowej diaspory oraz ankietowych badań Polaków (do badania tej grupy włączyłem też ankietę internetową - CAWI). Badaniem zasadniczym objęto stu członków diaspory arabskiej oraz stu Polaków w dwunastu miastach Polski, w których znajdują się oddziały organizacji polsko-arabskich oraz w których odnotowuje się najliczniejsze lokalne skupiska diaspory arabskiej; szczegółowe wyniki ww. badań są dostępne w publikacji Społecz̧ność arabska w Polsce. Stara 
zwrócić uwagę, iż część uwag i opinii respondentów ma charakter uniwersalny, dotyczy wszystkich imigrantów w Polsce, nie tylko wspomnianej społeczności.

Programy integracyjne jak dotąd są skierowane tylko do osób objętych ochroną międzynarodowa, wyjątek stanowią działania podejmowane na rzecz integracji obywateli państw trzecich w Polsce. Społeczność arabska w Polsce w niewielkim stopniu składa się z osób objętych ochroną międzynarodowa, zdecydowana większość to osoby, który przyjechały do Polski na studia lub przebywają w Polsce z powodu małżeństwa (większość diaspory arabskiej w Polsce stanowią mężczyźni). Badani członkowie diaspory nie uważają się za imigrantów, ponieważ ich pobyt w Polsce nie jest typową imigracja zarobkowa. W większości są to bardzo dobrze zintegrowani, a nawet zasymilowani przedstawiciele diaspory arabskiej, którzy ukończyli w Polsce studia (dotyczy to zwłaszcza starej diaspory); sa rozproszeni, funkcjonują w polskich rodzinach i na polskim rynku pracy, niejednokrotnie prowadząc własne firmy. Widoczna jest zależność, że im lepiej osoby te znaja język polski i dłużej mieszkają w Polsce, tym lepiej są zintegrowane, mimo że nie były objęte żadnymi programami na rzecz integracji. Jeśli jednak stosowne władze Polski chciałyby stworzyć efektywną politykę integracyjna, mogłyby skorzystać z przedstawionych $\mathrm{w}$ tym artykule rekomendacji.

Respondenci z diaspory arabskiej byli rekrutowani z zachowaniem podziału według daty przyjazdu do Polski - tych, którzy przyjechali do Polski w ostatnich latach uznać można za „nową" diasporę (50 respondentów - w skrócie ND), natomiast ci, którzy przyjechali do Polski przed 1989 rokiem i tu pozostali, tworzą „starą" diasporę arabską w Polsce (50 respondentów - SD). Wśród badanych Polaków wyodrębniły się trzy grupy: Polacy przychylni (PP), nieprzychylni (PN) oraz „niezdecydowani” (TP), czyli tacy, którzy na pytanie: „Czy jesteś przychylny arabskiej społeczności w Polsce?”, wybrali odpowiedź: „trudno powiedzieć”. Najwięcej osób - około 2/3 badanych Polaków określiło siebie jako przychylnych, najmniej jako nieprzychylnych badanej społeczności. Osoby niezdecydowane podawały jako wyjaśnienie tego wyboru najczęściej fakt, że nie mają nic przeciwko pojedynczym osobom pochodzenia arabskiego, sa jednak przeciwne masowej imigracji z krajów arabskich. W dalszej części artykułu zaprezentowano przykładowe wypowiedzi uczestników badań odnośnie do kwestii powiązanych z procesem integracji.

i nowa diaspora (Switat 2017); do przeprowadzenia nowej analizy w artykule wykorzystano fragmenty tej monografii. 
Kwestia integracji cudzoziemców nie jest w Polsce istotnym problemem społeczno-politycznym z uwagi na małą liczebność cudzoziemców i nieznaczną imigrację. Z tego powodu historia polityki integracyjnej jest stosunkowo krótka. Kwestie samej migracji stały się przedmiotem regulacji dopiero w latach transformacji (1989-2001), wówczas ustawodawstwo dotyczące tego procesu przeszło fazę instytucjonalizacji. W latach 2001-2004 nastąpiła europeizacja polskiego prawa migracyjnego. W tym okresie po raz pierwszy pojawiła się kwestia integracji cudzoziemców, m.in. w 2004 roku wprowadzono ustawę o pomocy społecznej, obejmującą uregulowania o programach integracyjnych dla uchodźców (Lesińska, Stefańska, Szulecka 2010, 262-264).

Aspekty polityki integracyjnej zostały określone w dokumencie pt. Propozycje driatań w kierunku stworzenia kompleksowej polityki integracji cudzoziemcón w Polsce, przyjętym przez Komitet Europejski Rady Ministrów w 2005 roku, a problematyka integracji cudzoziemców stała się przedmiotem dalszych opracowań. Z kolei w 2013 roku, w efekcie prac Grupy Roboczej ds. Integracji Cudzoziemców przy Zespole ds. Migracji, opublikowano projekt Polska polityka integracji cudzoziemcón - założenia i uytyczne, na podstawie dokumentu zawierającego założenia polskiej polityki migracyjnej pt. Polityka migracyjna Polski - stan obecny i postulowane driałania opublikowany w 2012 roku. Tę strategię migracyjną Rada Ministrów unieważniła 18 października 2016 roku jako nieuwzględniającą możliwości reakcji na kryzys uchodźczy w Europie oraz imigrację ekonomiczną z Ukrainy. Dokument o integracji formalnie nigdy nie wszedł w życie, choć - opublikowany później niż dokument o polityce migracyjnej - był w stosunku do niego tylko uzupełnieniem. Z informacji podanych na stronie Ministerstwa Inwestycji i Rozwoju wynika, że w 2018 roku Rada Ministrów przyjęła Nowe priorytety społeczno-gospodarcze polityki migracyjnej. Prace nad opracowaniem kompleksowej polityki migracyjnej nie zostały jeszcze zakończone, brakuje też informacji, czy uregulowane zostaną w niej także kwestie związane z integracją imigrantów.

Istnieje wiele definicji samego procesu integracji ${ }^{2}$. Integracja dla arabskich respondentów to przede wszystkim interakcje z polskim środowiskiem,

\footnotetext{
2 Za najtrafniejszą definicję integracji dla swoich badań przyjąłem definicję Leo R. Chaveza (1991), który twierdzi, że pełne włączenie imigranta do społeczności przyjmującej polega nie tylko na zmianach dotyczących migranta, ale i na tym, czy społeczeństwo przyjmujące jest gotowe „wyobrazić” sobie migrantów danej kategorii (u Chaveza nieudokumentowanych) jako członków swej wspólnoty. Wśród innych definicji są m.in. te nawiązujące do ogólnych zasad integracji jako relacji między społeczeństwem przyjmującym a przybyszami (Entzinger,
} 
przyjęcie elementów polskiej kultury, nauka języka oraz poszanowanie miejscowego prawa. Ponadto prawie wszyscy arabscy respondenci stwierdzili, że członkowie diaspory powinni się dostosować do społeczeństwa polskiego i mieć te same obowiązki społeczne. To dostosowanie się do społeczeństwa przyjmującego według części badanych Polaków jest właśnie integracja. Obydwie badane grupy za najlepszy model współistnienia w jednym państwie wybrały integrację z częściowym zachowaniem własnej kultury (równoważność kultur). Część respondentów arabskich stwierdziła również, iż niektórzy członkowie arabskiej diaspory przejęli elementy kultury polskiej:

niektórzy przejęli i doświadczyli tych elementów tak samo jak Polacy, tradycję i zwyczaje - okazje religijne i kulturalne, ubiór, wszystko, zachowuja się jak Polacy, odróżnić ich można tylko pod względem koloru skóry $(\mathrm{ND} 29)^{3}$,

a ich przejęcie uznali za automatyczną integrację.

Ponad połowa badanych przedstawicieli diaspory arabskiej uznaje swój stopień integracji na minimum średnim poziomie, o ich dobrej integracji świadczy uwaga jednego z Polaków:

znane są osoby pochodzenia arabskiego, które znają kulturę i historię Polski lepiej od niejednego Polaka (PP16),

a 54\% reprezentantów nowej diaspory chce się bardziej zintegrować ze społeczeństwem polskim (Switat 2015). Arabscy respondenci wskazywali też rzeczy, których się od Polaków nauczyli - nie tylko języka polskiego, ale i m.in. porządku, cierpliwości, punktualności, samoorganizacji i wytrwałości. Potwierdza to proces akulturacji, czyli stopniowego przejmowania przez imigrantów głównych elementów otaczającego ich środowiska kulturowego - bez całkowitej rezygnacji z ich pierwotnej tożsamości kulturowej (Entzinger, Biezeveld 2007, 29), któremu podlega ta społeczność w Polsce.

Badani członkowie społeczności arabskiej zwrócili uwagę, że integracja cudzoziemców (w tym zwłaszcza uchodźców) powinna być nastawiona na ich szybkie usamodzielnienie ekonomiczne i społeczne. To powinno być podstawą państwowych programów. W tej chwili od każdego imigranta, już

Biezeveld 2007), autoanalizy społeczeństwa przyjmującego (Scheffer 2010) czy zmiany tożsamości (Burszta 2004).

${ }^{3} \mathrm{~W}$ przytoczonych wypowiedziach respondentów zachowano pisownię oryginalną - M.S. 
od chwili przyjazdu do Polski, oczekuje się samodzielności - sam musi zadbać o legalizację pobytu (m.in. wypełnić wniosek w języku polskim, pozyskać niezbędne dokumenty, zapewnić sobie tłumacza, opłacić procedury i przedstawić źródła dochodu w Polsce).

Pomoc w pierwszych krokach na rzecz samodzielności, a jednocześnie integracji przedstawicieli arabskiej diaspory była i jest w dużej mierze scedowana na tzw. podmioty niepaństwowe (to na nich spoczywa ciężar i niejako obowiązek wsparcia cudzoziemca w integracji oraz funkcjonowaniu w polskiej rzeczywistości):

- na polskich małżonków i ich polskie rodziny (w przypadku imigrantów-małżonków polskich obywateli);

- na uczelnie, opiekunów zagranicznych studentów i polskich bądź cudzoziemskich kolegów (w przypadku uczniów, studentów czy doktorantów);

- na rodaków, którzy przyjechali do Polski wcześniej (inni imigranci);

- na instytucje pozarządowe.

Należy zwrócić uwagę, iż integracja części przedstawicieli diaspory arabskiej (zwłaszcza ze starej diaspory) dokonała się samoistnie i naturalnie, bez jakiejkolwiek ingerencji państwa czy wsparcia instytucjonalnego. Wysoki stopień integracji zwłaszcza starej diaspory arabskiej może potwierdzać fakt, że brak specjalnych programów integracyjnych nie jest przeszkoda w procesie integracji. Skoro w Polsce nie ma przyjętego modelu integracji imigrantów, to dotychczasową politykę integracji cudzoziemców w Polsce można by nazwać modelem not-definded integration, inaczej podejście do tej kwestii zostało określone w Ekspertyzie podsumownjacej doswiadczenia teoretyczne $i$ empiryczne nad spotecznym i ekonomicznym nymiarem integracji (2007) - jako polityka „asymilacji przez porzucenie”, ponieważ większość grup imigranckich jest generalnie pozostawiona samym sobie, przy jednocześnie niskim poziomie akceptacji społecznej dla różnic kulturowych, a zwłaszcza etnicznych. Not-definded integration można by zdefiniować jako brak określenia szczegółowych kwestii integracji i pozostawienie jej naturalnemu biegowi, przy jednoczesnym zabezpieczeniu respektowania praw i obowiązków społeczeństwa przyjmującego i cudzoziemców oraz przeciwdziałaniu gettyzacji i dyskryminacji.

Być może w stosunku do osób, które znają język polski bardzo dobrze (dzięki na przykład ukończeniu studiów w Polsce) i pozostają w binacjonalnym związku małżeńskim z polskim obywatelem (jak badana społeczność), jest to najlepsza forma integracji. Małżeństwo binacjonalne (transnacjonalne) 
to bowiem szczególny rodzaj kontaktów kulturowych i rzeczywisty proces głębokiej i bezdyskusyjnej integracji pomiędzy przedstawicielami różnych narodowości i kultur (Nowicka 2011). Programy integracyjne powinny być zatem skierowane głównie do osób, które przyjeżdżaja do Polski z innych powodów niż studia i małżeństwo z polskim obywatelem.

Wiele się ostatnio dyskutuje na temat skuteczności integracji, zwłaszcza w kontekście jej braku czy słabej integracji pewnych grup imigrantów w krajach zachodnich (oskarżani sa o to m.in. Arabowie, muzułmanie); z kolei imigranci z krajów wschodniego sąsiedztwa są uważani za łatwo się integrujących z lokalnymi społecznościami (Zespół MSW 2012, 34). Rodzi się przy tym pytanie: skąd wniosek sugerujący, iż pozostali imigranci integrują się trudniej? Dotąd nie zebrano w Polsce odpowiednich danych pozwalających analizować poziom integracji wszystkich imigrantów, z tego też powodu badania nad integracją imigrantów w Polsce stanowia pewnego rodzaju ghost study. Należałoby przeprowadzić takie badania (zastosować dostępne wskaźniki i teorie na rzecz badań własnych imigrantów), aby poznać stopień integracji w poszczególnych wymiarach: społeczno-ekonomicznym, kulturowym, prawno-politycznym oraz stosunek społeczeństwa przyjmującego (Etzinger, Biezeveld 2003). Można by ponadto wdrożyć monitoring procesu ich integracji. Mogłaby być to ankieta ewaluacyjna opracowana przez interdyscyplinarny zespół naukowców (na przykład socjologów, psychologów, kulturoznawców) wypełniana przez imigrantów przy okazji wymiany karty pobytu - podobne rozwiązanie proponowano w projekcie polskiej polityki integracyjnej (Zespół ds. Migracji 2013, 28).

Taka ankieta mogłaby z drugiej strony spełniać rolę komunikacyjno-informacyjna pomiędzy administracja państwową a imigrantami, jeśli część pytań dotyczyłaby oceny obsługi, procedury pobytowej, prawa pobytowego. Polska polityka integracyjna (migracyjna) jak dotąd jest tworzona głównie przez Polaków, udział samych imigrantów jest ograniczony lub tylko pośredni, poprzez organizacje pozarządowe zajmujące się sprawami imigrantów i nieliczne stowarzyszenia niektórych społeczności cudzoziemców (diaspora arabska nie ma organizacji reprezentującej jej sprawy). Indeks Polityki Migracyjnej od kilku lat systematycznie pokazuje poważne braki Polski w stworzeniu podstaw prawnych do integracji prawno-instytucjonalnej. Oznacza to, iż większość imigrantów w kraju ma bardzo ograniczone możliwości wpływania na kształt polityki, która ich dotyczy w codziennym życiu (Brzozowski, Pędziwiatr 2014). Zaproponowana ankieta ewaluacyjna mogłaby być głosem tych społeczności w sprawach, które ich bezpośrednio do- 
tycza, co nie wyklucza jednocześnie prowadzenia działań pozwalających na wsparcie organizacji zrzeszających imigrantów w zakresie aktywnego współistnienia w społeczeństwie obywatelskim.

Pierwszy symptom sukcesu integracji jest powiązany z uczestnictwem imigrantów w rynku pracy (ewentualnie z samozatrudnieniem) oraz z czynnikami mającymi na to wpływ, jak edukacja czy znajomość języka (Entzinger, Biezeveld 2007, 43). Większość arabskich respondentów pracuje, część z nich zwróciło jednak uwagę na potencjał osób objętych ochroną międzynarodową, który nie jest właściwie wykorzystywany. Programy integracyjne nie służą w pełni integracji tych osób, sprawiają, iż stają się oni niepełnosprawni społecznie:

Polacy chca, żeby przyjechali ludzie na azyl polityczny, zamknąć ich w obozie itd., ale robią w ten sposób z nich inwalidów, ale potem, jak wychodza po kilku latach z tego obozu, to oni do niczego nie sa zdolni, a to w interesie Polski jest, żeby tu nie tworzyć inwalidów, dobra, chca być w tym obozie? to trzeba ich szkolić, jeden stolarz, drugi rzeźnik, trzeci kowal, czwarty mechanik samochodowy, to niech Polska korzysta z ich możliwości, a nie tylko ich zamykać, (...), ale potem jak wychodzą będą kalekami i problemem dla polskiej gospodarki (SD25).

Także jeden z polskich respondentów na pytanie, jak państwo powinno pomagać imigrantom, odpowiedział:

najpierw obowiązkowy kurs języka polskiego, z zabezpieczeniem lokum do życia, potem kursy przystosowujące do wykonywania zawodu (przekwalifikujące), aby ułatwić imigrantom start zawodowy (PP42).

Warto być może wprowadzić eksperymentalny, pilotażowy program aktywizacji tej grupy cudzoziemców (lub innych imigrantów), program może być współprowadzony z sektorem prywatnym - pracodawcy mogą przyjmować na staż pojedyncze osoby lub niewielkie grupy uchodźców w celu nauki nowych umiejętności, a najlepszych uczestników zatrudniać po zakończeniu stażu. Z uczestnikami tego programu mogłyby być np. podpisywane zobowiązania bądź umowy z klauzulą lojalności, że w przypadku wyjazdu z Polski uchodźca/imigrant musi zwrócić część poniesionych kosztów.

Jedną z najważniejszych cech integracji jest fakt, że jest to proces dwustronny, angażujący zarówno imigrantów, jak i społeczeństwo przyjmujące. Badani Polacy w stosunku do diaspory arabskiej, podobnie jak w każdej in- 
nej kwestii, przejawiaja generalnie trzy postawy: sympatię, antypatię lub obojętność - czyli od ksenofilii do ksenofobii czy innych negatywnych mechanizmów społecznych powiązanych z postrzeganiem „obcości” i odmienności, tj.: rasizm, dystans społeczny, uprzedzenia, stygmatyzacja, marginalizacja, wykluczenie, nietolerancja, negatywna etykietyzacja oraz stereotypizacja. W konsekwencji uprzedzeń członkowie diaspory arabskiej stają się czasem ofiarami antylokucji (antilocution), czyli werbalnego wyrażania uprzedzeń, unikania, dyskryminacji, ataków fizycznych (Allport 1979/1958/1954) oraz mowy nienawiści (zwłaszcza Arabowie-muzułmanie, którzy ponadto doświadczaja przypadków „rasizmu antymuzułmańskiego”, czyli islamofobii będącej głównie przeniesieniem zachodniej retoryki i problemów, niewspółmiernych do sytuacji w Polsce).

Za główną przeszkodę w integracji uważane są właśnie antyimigranckie nastroje miejscowej ludności. Niełatwo jest zwalczać głęboko zakorzeniony rasizm i ksenofobię, a same kampanie społeczne rzadko przynoszą pożądany skutek. Najlepszą metodą walki ze zjawiskiem rasizmu jest danie szansy imigrantom, co umożliwia im sukcesywną integrację (Etzinger, Biezeveld 2003). Jest to istotne nie tylko $\mathrm{w}$ aspekcie lokalnym, imigranci są przecież ambasadorami Polski poza jej granicami - nie tylko w swoich krajach, ale i na całym świecie.

Społeczeństwo polskie trzeba w pewnym sensie „oswoić”, przyzwyczaić do cudzoziemców poprzez zwiększenie pozytywnych interakcji Polaków z imigrantami (część już w tej chwili ma kontakty z cudzoziemcem-lekarzem, sprzedawcą na bazarze czy w lokalu gastronomicznym itp., jednak w innych dziedzinach życia publicznego i na rynku pracy imigranci są ciagle niewidoczni), a imigrantów społeczeństwo powinno sobie wychować. Cudzoziemcy po przyjeździe do nowego kraju są jak dzieci, potrzebuja poznania, nauki i pomocy. Zdaniem Jacka Kubitsky'ego samotność to podstawowe uczucie każdego migranta, jest ono szczególnie uciążliwe w pierwszych miesiącach pobytu w nowym miejscu, kiedy przybysz potrzebuje najbardziej życzliwego towarzystwa i opieki (Kubitsky 2012, 127). Początkowe stadium integracji to zatem stadium wychowania, bo bez troskliwej opieki, jak niedopilnowane dziecko, w „życiu dorosłym” przybysze moga albo przynieść danemu społeczeństwu problemy, albo „wyrosna” na rozumnych obywateli, którzy odwdzięczą się za pomoc sumienną pracą na rzecz wspólnego dobra.

Imigranci w Polsce to przecież część polskiego społeczeństwa. Żyjąc razem na tym samym terenie, obok siebie, należy działać wspólnie - na rzecz 
dobra kraju, w którym razem się mieszka. Poza tym cudzoziemcy, którzy mieszkają w Polsce, są dla Polaków w pewnym sensie „naszymi” (swoimi) cudzoziemcami. Teraz imigranci, ale z czasem długoterminowi rezydenci, osoby osiedlone bądź nawet obywatele. Imigrant, żeby gdzieś żyć, nie potrzebuje obywatelstwa, ale obywatelstwo wiąże człowieka z miejscem oraz jest konsekwencja jego przywiązania i powiązań z danym krajem (w tym także kulturowych).

Należy zwrócić uwagę, jak bardzo rasizm i dyskryminacja utrudniają integrację. Według Amina Maaloufa, im bardziej imigranci czują iż tradycja ich pierwotnej kultury jest szanowana w nowej ojczyźnie, a im mniej, że z powodu odmiennej tożsamości ich się nienawidzi, wypycha, straszy, dyskryminuje - tym chętniej otwieraja się na propozycje kulturowe nowego kraju i tym mniej kurczowo trzymają się swej odrębności (Maalouf 2002). Tę teorię potwierdzają badania German Marshall Fund (Wunderlich i in. 2009) na temat trendów imigracyjnych - 36\% ankietowanych w sześciu państwach unijnych (szczególnie we Włoszech i Francji) uważa, iż dyskryminacja imigrantów jest większą przeszkodą w ich integracji niż brak woli integracji ze strony samych imigrantów. Przytoczone opinie potwierdzaja przykładowe wypowiedzi respondentów arabskich:

Arab zupełnie się integruje, jeśli ma tu pracę i jeśli jest traktowany z szacunkiem, to jest najlepszy sposób, (...) bo jak człowiek ma pracę i wszystko, on się integruje podświadomie i naturalnie, jednak ogranicza integrację czasami, kiedy ktoś ci przypomina, że nie jesteś Polakiem albo coś w stylu rasistowskim, co daje powody do zastanowienia się nad integracja (SD19).

Zatem, żeby imigrant chciał się integrować - m.in. musi mu na to zezwolić i zachęcić społeczność przyjmująca. Występuje tu pewnego rodzaju dychotomia - Polacy (jak inne narody) oczekuja od społeczności (nie tylko arabskiej) integracji lub nawet asymilacji, jednak odmawiają znaturalizowanym cudzoziemcom prawa do polskości. Jak bowiem wskazują badania społecznych kryteriów polskości według OBOP (2008), w opinii Polaków w latach 1988-1998-2008 istotne są dwa kryteria: urodzenie w Polsce (ważne lub bardzo ważne dla ok. 60\% Polaków) i wiara katolicka (dla ponad 40\%) - niemożliwe do spełnienia przez znaczną część imigrantów.

Arabowie ze starej diaspory zwracali uwagę na fakt, iz Polakom trudno jest się przyzwyczaić, że osoby o niesłowiańskim wyglądzie czy nazwisku 
moga mieć polskie obywatelstwo. To Polacy arabskiego pochodzenia, jednak choć posiadaja polski dowód osobisty, inni („typowi”) Polacy nadal określają ich, używając słów i zwrotów o pejoratywnym wydźwięku: „ten śniady”, „ten obcokrajowiec”; pytaja - „skąd Pan jest, skąd pan przyjechał?” (ND49). Jak wykazały badania, 54\% osób pochodzenia arabskiego posiadających polskie obywatelstwo, twierdzi, że czuje się Polakiem pomimo swojego arabskiego pochodzenia, np.:

w tym kraju mam dzieci i żonę, i środki do życia, więc dlatego czuję się Polakiem (ND25).

To utożsamianie się z polskością i odczuwanie identyfikacji z Polakami świadczy o ich wysokim stopniu integracji (Switat 2015).

Z polskimi Arabami/Polakami arabskiego pochodzenia (ale także z innymi cudzoziemcami, którzy zostali znaturalizowani, tzw. quasi-obywatelami) łączy się pewna ważna kwestia tożsamościowa - osoby te obecnie są Arabami z polskim obywatelstwem (tożsamość złożona $\mathrm{z}$ racji funkcjonowania w dwóch kulturach). W efekcie tego zjawiska są albo dwutożsamościowi, albo wytwarza się u nich nowa, wewnętrznie zintegrowana tożsamość, inna jednak od tożsamości wyjściowej - etnicznej czy kulturowej (Babiński 1997). Jednak ich dzieci, zwłaszcza jeśli zostaną w Polsce i poślubią Polkę/Polaka, będa już pół Arabami, pół Polakami, a wnuki i kolejne pokolenia będą już prawdopodobnie w pełni Polakami, którzy tylko mieli dziadka, pra(...)dziadka Araba, zatem w ciagu kilku pokoleń nastapi prawdopodobnie przemiana tożsamości społecznej potomków arabskich imigrantów (spolszczenie).

Biorąc zaś pod uwagę integrację kulturowa, podział społeczności arabskiej w Polsce na dwie subdiaspory powinien być dokonany nie ze względu na kryterium daty przyjazdu do Polski, a według znajomości języka polskiego. Język polski znaja wszyscy badani Arabowie w Polsce - ponad 82\% na poziomie minimum dobrym, poza tym $90 \%$ Arabów w Polsce zna też dobrze polską kulturę i historię oraz sławnych Polaków, a 88\% interesuje przyszłość Polski. 41\% badanych Polaków ma kontakty prywatne z przedstawicielami arabskiej społeczności w Polsce, a prawie 90\% respondentów arabskich zadeklarowało kontakty prywatne z Polakami, m.in. członkami rodziny, przyjaciółmi, kolegami (Switat 2015). Można więc wysnuć wniosek, iż (abstrahując od indywidualnych predyspozycji i czynników zależnych od społeczeństwa przyjmującego) o powodzeniu integracji decyduje przede wszystkim znajomość języka polskiego i historii Polski (studia w Polsce), małżeństwo 
z polską obywatelką / polskim obywatelem i tym samym przynależność do polskiej rodziny, status społeczny (w tym kwestia podstawy pobytu) oraz sytuacja na rynku pracy (stabilne zatrudnienie, niezależność finansowa, kwalifikacje).

Podsumowując, integracja imigrantów może się dokonać samoistnie, kiedy spełnione zostaną pewne warunki - głównie nauka języka polskiego, co umożliwi jak najszybsze wejście na rynek pracy (zatrudnienie lub prowadzenie własnej działalności) i pozytywne interakcje z polskim społeczeństwem. Badania arabskiej diaspory dowodzą, że od państwa należałoby oczekiwać pomocy głównie w nauce języka polskiego oraz przeciwdziałaniu rasizmowi i walce ze stereotypami. Zalecane jest poznanie imigrantów mieszkających w Polsce i rzetelne informowanie o nich społeczeństwa oraz podkreślanie różnic pomiędzy problematyką imigracyjną w Polsce i w krajach zachodnich. Zapewnienie równych szans społecznych imigrantom może sprawić, że żadna specjalna polityka integracyjna nie będzie potrzebna.

\section{Literatura}

Allport G.W., 1979/1958/1954, The nature of prejudice (25th Anniversary Edition), New York.

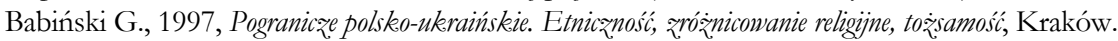

Brzozowski J., Pędziwiatr K., 2014, Analiza procesu integragi imigrantón w Matopolsce, w: Pindel E., red., Imigranci w Małopolsce. Międyy integracja, asymilacja, separacja, marginalizacja, Kraków. Burszta W., 2004, Różnorodność i to żsamość. Antropologia jako kulturowa refleksyjność, Poznań.

Chavez L.R., 1991, Outside the Imagined Community: Undocumented Settlers and Experiences of Incorporation, "American Ethnologist", Vol. 18 (2).

[Ekspertyza 2007] Ekspertyza podsumownjaca dóswiadczenia teoretyczne i empiryczine nad spotecznym i ekonomicznym nymiarem integracji. Modut III. Integracja cudzoziemcón w Polsce, 2007, Warszawa.

Etzinger H., Biezeveld R., 2003, Benchmarking in Imigrant Integration, Rotterdam.

Entzinger H., Biezeveld R., 2007, Zasady integragi imigrantón, w: Balicki J., red., Integracja kulturowa imigrantón. Wyzpania i dylematy, Warszawa.

Kubitsky J., 2012, Psychologia migracji, Warszawa.

Lesińska M., Stefańska R., Szulecka M., 2010, Rozpój polityki migracyjnej Polski, w: Górny A., Grabowska-Lusińska I., Lesińska M., Okólski M., red., Transformacja nieoczyynista. Polska jako kraj imigracji, Warszawa.

Maalouf A., 2002, Zabójcze tołssamości, przeł. Lisowska-Chehab H., Warszawa.

[MIRR 2018] Ministerstwo Inwestycji i Rozwoju, 2018, Nowe priorytety rzadowej polityki migracyj$n e j$, https://www.miir.gov.pl/strony/aktualnosci/nowe-priorytety-rzadowej-polityki-migra cyjnej [dostęp: 04.09.2018].

Nowicka E., 2011, Wprowadzenie, w: Nowicka E., red., Blaski i cienie imigracji. Problemy cudzoziemcón w Polsce, Warszawa.

OBOB, 2008, Spoteczne kryteria polskości, 1988-1998-2008, Warszawa. 
Scheffer P., 2010, Druga ojczyzna. Imigranci w społeczeństwie otwartym, przeł. Jusewicz-Kalter E., Wolowiec.

Switat M., 2015, Spotecznosić arabska w Polsce - fakety i mity. Raport z badań, „Przegląd Orientalistyczny", nr 3-4.

Switat M., 2017, Spoteçność arabska w Polsce. Stara i nowa diaspora, Warszawa.

Wunderlich T., Ziebarth A., Gustin D., Isernia P., Diehl C., Martin S., 2009, Transatlantic Trends: Immigration, German Marshall Fund, Ann Arbour, MA, https://www.icpsr. umich.edu/icpsrweb/ICPSR/studies/31801 [dostęp: 12.09.2018].

[Zespół MSW 2012] Zespół do Spraw Migracji MSW, 2012, Polityka migracyjna Polski - stan obecny i postulowane driatania, Warszawa.

[Zespół ds. Migracji 2013] Grupa Robocza ds. Integracji Cudzoziemców przy Zespole ds. Migracji, 2013, Polska polityka integracji cudzoziemcón - założenia i wytycžne, [projekt], Warszawa. 